\title{
РЕАЛІЗАЦІЯ АКСІОЛОГІЧНОЇ ПСИХОТЕХНОЛОГІЇ В ПРОФЕСІЙНІЙ ПІДГОТОВЦІ МАЙБУТНЬОГО ПСИХОЛОГА
}

\author{
Булах І. С., Волошина В. В.
}

\section{ВСТУП}

Смисли не дані нам, ми не можемо вибрати собі смисли, ми можемо лише обрати покликання, в якому знайдемо смисл.

В. Е. Франкл

На сучасному етапі розвитку суспільства в умовах реформування вітчизняної освіти постає необхідність внесення змін до вже відпрацьованих освітніх технологій i, відповідно, технологій професійної підготовки майбутнього психолога. Сьогодні значущими $\epsilon$ інноваційні технології, які дозволяють максимально наблизити й спрямувати освітній процес безпосередньо до майбутнього професійного середовища фахівця 3 урахуванням його вподобань, індивідуальних можливостей, мотивів та особистісних цінностей. Водночас професійна підготовка молодого покоління жодним чином не мусить відставати від суспільного чи економічного розвитку, а навпаки, випереджати їх, пропонуючи нові креативні й технологічні підходи. У цьому аспекті оновлення процесу професійної освіти майбутніх психологів викликане імплементацією європейського освітнього досвіду у вітчизняний контент, активізацією міжнародної та національної мобільності фахівців i, безумовно, активним запровадженням цифровізації в закладах освіти, що суттєво змінює роль не лише викладача, а й самого студента.

Суспільство створює запити на зміну якості фахових психологічних послуг. Із кожним роком психологічне консультування й тренерство впевнено утверджується на ринку праці. Труднощі до адаптації в нових кризових умовах життедіяльності, сучасне інформаційно-технічне та соціально-політичне навантаження, відсутність можливості до планування і прогнозування власних дій, підвищений рівень тривожності змушують особистість шукати підтримки в психологів-консультантів, які були б спроможними приймати ії індивідуальність та неординарність життєвих виборів. Тому й технології професійної підготовки майбутніх психологів у закладах вищої освіти мають відповідати вимогам i потребам особистості, яка живе в змінених умовах технологізованого світу. Сьогодення потребує особистісно орієнтованих психологів- 
практиків, які б відчували й розуміли тонкий внутрішній і духовний світ особистості, володіли техніками організації й управління свідомістю, вміли розкривати потенційні можливості психічних процесів та станів особистості тощо. Здійснити такий крок у бік перебудови освітнього процесу, зокрема професійної підготовки фахових психологів, дозволяють нові аксіологічні психотехнології освітнього процесу, спрямовані на формування, прогнозування поведінки i корекцію психологічної організації особистості майбутнього фахівця.

Згадаємо, що ідейним натхненником технологічного напряму в психології на початку XX століття був Л.С. Виготський, який розглядав психотехніку як один із головних методів формування психіки. За його переконанням, використання психотехніки має розвивати перцептивні вміння й відображати переживання інших, формувати експресивний репертуар особистості та умови для емоційного обміну, сприяти встановленню контакту з оточенням. Саме Л.С. Виготському ${ }^{1}$ належить виокремлення в структурі психологічної науки чотирьох рівнів розуміння предмета дослідження, зокрема теоретичного, експериментального, методологічного й психотехнічного (як єдність прикладної й практичної психологіï).

Не вдаючись до детального історичного аналізу становлення психологічних технологій у вітчизняній науці, слід указати, що сьогодні в психології використовуються технології особистісного зростання, технології самопізнання, саморозвитку, самореалізації, самопрограмування, саморегуляції, самоствердження й самопрезентації, психотехнології розвитку мотиваційної, когнітивної та емоційної сфер особистості, комунікативні психотехнології, технології евристичного навчання тощо.

\section{1. Теоретико-методологічне підгрунтя реалізації аксіопсихотехнології професійної підготовки майбутнього психолога}

Основними ознаками психотехнологій $є$ такі: спрямованість на зміну поведінки людини, іiі настроїв, ставлень, мотивів, цінностей; орієнтованість на вирішення конкретних проблем особистості або групи людей; аналіз i врахування конкретного соціального і природного психологічного контексту, в якому перебуває особистість; наявність цілей, що розкривають мету та зумовлюють планування і змістове наповнення етапів діяльності; мультидисциплінарний характер (залучення знань, методів, прийомів із різних галузей науки і практики); взаємозв'язок i взаємозумовлення діагностичних, формувальних (коригувальних) й оцінних складників; гнучкий

${ }^{1}$ Выготский Л.С. Проблемы развития психики : т. 3. Собрание сочинений : [в 6-ти т.] / под ред. А.М. Матюшкина. Москва : Педагогика, 1983. 368 с. 
характер застосування окремих прийомів і методів для розв'язання життєвих проблем людини; послідовність дій (алгоритм дій), у яких відображається образ продукту діяльності психолога.

Як слушно зазначила Л.В. Лежніна ${ }^{2}$, в практиці університетської підготовки майбутніх психологів поки що відсутня система їх продуктивного особистісно-професійного розвитку, оскільки домінантними залишаються репродуктивні методи навчання. Як наслідок, становлення психолога як суб'єкта обраної діяльності відбувається після закінчення закладу вищої освіти методом «проб і помилок» у сфері практики, що не відповідає тим вимогам, на які орієнтоване суспільство в отриманні послуг професійного психолога.

Слід зазначити, що наявні сьогодні психологічні технології професійної підготовки майбутнього психолога орієнтовані здебільшого на один із чинників (професійні практичні вміння та смислові установки, професійна свідомість і самосвідомість тощо), який ученими вважається домінантним у становленні професійності психолога. При цьому технології, які б забезпечували системність, цілісність і безперервність у процесі підготовки психологів, формували б ціннісне ставлення до обраного фаху та систему професійних цінностей i потенційних можливостей майбутнього психолога, відсутні. Крім того, зазначимо, що вченими майже не досліджується професійність психолога як аксіологічний феномен, від якого залежить успіх його соціальної адаптованості, самореалізації, конкурентоспроможності, становлення самоцінності й задоволеності життям у цілому.

Ми розуміємо психологічну технологію професійної підготовки майбутнього психолога як інтегративну модель фахового становлення особистості, в основі якої лежить алгоритм логічно виваженої, взаємопов'язаної системи психологічних впливів за допомогою психотехнік, спрямованих на активізацію внутрішніх механізмів особистості, які запускають свідоме і творче перетворення студентомпсихологом ціннісно-смислового поля майбутньої професійної діяльності.

На наше переконання, психологічна технологія професійної підготовки майбутнього психолога має стати цілеспрямованою технологією ліквідації розриву між опануванням майбутнім психологом теоретичних знань під час навчання в закладі вищої освіти, системою особистісних цінностей, розвитком індивідуальних здібностей та становленням його професійних цінностей, формуванням фахових компетентностей. Логіка іiї побудови має враховувати соціальні умови та психологічні механізми становлення майбутнього

2 Лежнина Л.В. Комплексная технология разбора кейсов в подготовке психологов образования. Психология образования: современное состояние и перспективы : материалы II Всеросс. науч.-практ. конф. / под общ. ред. Е.Ю. Пряжниковой. Славянскна-Кубани : Издательский центр СГПИ, 2008. С. 303-306. 
психолога як суб'єкта професійної діяльності та виконувати інтегративну функцію, зокрема завдяки актуалізації когнітивноемоційної єдності, об’єктивації особистісних цінностей, що сприятиме становленню професійних цінностей фахівця.

Сьогодні чітко зрозуміло, що наявні психотехнічні відмінності в професійній взаємодії між психологом-консультантом і клієнтом та ведучим тренінгу й членами групи. Учена С.В. Васьківська ${ }^{3}$ наполягає на необхідності обгрунтування диференційованої профільної підготовки спеціалістів у галузі психології, що мають різні моделі професійної діяльності. Так, наявні в сучасній практиці моделі консультування реалізуються через систему порад i рекомендацій, «психологічне віддзеркалення іншого», превентивну підтримку клієнта 3 метою запобігання ускладнень (Л.Б. Шнейдер) ${ }^{4}$, усвідомлення клієнтом відповідальності за власну життєдіяльність (I.С. Булах ${ }^{5}$, T.M. Титаренко $\left.{ }^{6}\right)$. Натомість тренінг як синтетична антропотехніка покладається в навчальні та ігрові ситуації (О.П. Ситніков) ${ }^{7}$, впорядковану сукупність активних методів ефективної групової роботи, багатофункціональні методи перепрограмування наявної в людини моделі управління власною поведінкою й діяльністю (Т.С. Яценко) ${ }^{8}$. До того ж, як стверджують фахівці з цієї галузі, особистісний вибір професії психолога детермінується особистісними мотивами (О.Г. Асмолов)9 професійними уявленнями, змістом конструктивної «Я-концепції» особистості, почуттям самоідентичності (Т.А. Казанцева) ${ }^{10}$ тощо. Отож,

3 Васьківська С.В. Основи психологічного консультування. Київ: Четверта хвиля, 2004. $256 \mathrm{c.}$

4 Шнейдер Л.Б. Профессиональная идентичность : монография. Москва : MOCУ, 2001. 272 c.

5 Булах I., Волошина В., Лохвицька Л. Сучасні освітні психотехнології професійної підготовки майбутніх психологів. 2019. URI: http://ekmair.ukma.edu.ua/handle/123456789/17080 https://doi.org/10.18523/26172348.2019.2.20-29

6 Титаренко Т.М. Життєві домагання і професійне становлення особистості практичного психолога. Практична психологія та соціальна робота. № 4. 2003. C. $15-18$.

7 Ситников А.П. Современные прикладные психотехнологии: процесс и язык коммуникации. Москва: РАУ, 1992. 276 с.

8 Яценко Т.С. Внутрішня динаміка психіки та іiі врахування в глибинній корекції. Науковий часопис Національного педагогічного університету імені М. П. Драгоманова. Серія 12 : Психологічні науки : зб. наук. праць. Київ, 2012. Вип. 37 (61). С. 6-10.

9 Асмолов А.Г. Психология личности: культурноисторическое понимание развития человека. Москва: Смысл: «Академия», 2007. 528 с.

10 Казанцева Т.А. Особенности личностного развития и профессионального становления студентов-психологов : дисс. ... канд. психол. наук : 19.00.11. Москва, 2000. $248 \mathrm{c}$. 
визначаючи напрям освітньої програми, майбутній психолог у процесі професійної підготовки має усвідомити свої здібності й компетенції та здійснити свідомий і осмислений вибір освітньої програми в межах психологічної спеціальності, зокрема чітко розуміти відмінності в моделях надання професійної допомоги клієнтам.

Наявний досвід діяльності в освітній галузі дозволяє нам стверджувати, що на етапі пошуку ефективних шляхів вирішення проблеми вдосконалення процесу професійної підготовки майбутніх психологів важливо враховувати той факт, що інноваційні психотехнології підготовки фахівця допоміжної професії мають бути зорієнтовані на особистість як самоцінність, котра осмислюе себе в широкому життєвому просторі через інтегративну єдність особистісних, професійних та соціальних цінностей. У процесі професійної підготовки важливо концентрувати увагу на етапах і механізмах розвитку ціннісної самосвідомості майбутнього фахівця та засобах і техніках надання психологічної допомоги тим, хто її потребує.

Метою психологічної технології підготовки майбутнього психолога має бути створення таких психолого-педагогічних умов, за яких студент мав би можливість зайняти активну особистісну позицію й повною мірою проявити себе як суб'єкт навчальної діяльності відповідно до власного професійного вибору, особистісних цінностей, власних переконань і здібностей, потреб, рівня домагань, мотивації та бажаного ідеального образу власного професійного майбутнього. Така технологія має передбачати активну взаємодію викладача й студента, активізацію внутрішніх та зовнішніх чинників професійного самовизначення майбутнього фахівця, а саме: розкриття потенційної мотивації, формування професійної ментальності, професійних ціннісних орієнтацій, особистісно-професійних якостей та реалізацію потреби в гармонізації реального й ідеального професійного «Я-образу» майбутнього психолога.

Зважаючи на вищезазначене, вважаємо, що базисом психологічної технології професійної підготовки майбутнього психолога має бути: 1) чітко сформована мета, зокрема визначена система професійних цінностей, властивостей, компетентностей, якими має володіти майбутній психолог-консультант, психолог-тренер, соціальний психолог, психолог-ребілітолог, політичний психолог тощо; 2) якісно визначена система особистісних цінностей, професійних ціннісних орієнтацій майбутніх фахівців відповідно до обраної освітньої програми; 3) спеціалізований відбір із метою вибору студентами (відповідно до особистих нахилів і здібностей) освітніх програм: психологічних тренінгових технологій, психологічного консультування, соціального психолога, психолога-реабілітолога, психосоматики тощо; 4) створені умови формування системи особистісних, соціальних, професійних цінностей та детермінантів професійної підготовки особистості майбутнього психолога. 
Лише технологія ступеневої підготовки майбутнього психолога, яка побудована на базі систематизації та покрокової реалізації конкретних цілей професійної підготовки, в основі якої лежать техніки активізації механізму об'єктивації системи особистісних цінностей, мотиваційної сфери, становлення системи професійних цінностей та врахування індивідуальних відмінностей на етапах розвитку особистості, іiї спроможності в засвоєнні професійних знань, формуванні компетентностей відповідно до професійних вимог та моделі обраної фахової діяльності, спроможна підготувати психолога, якого потребує сучасне суспільство.

Зважаючи на зазначене, підвищення рівня ефективності професійної підготовки майбутнього психолога потребує збагачення освітніх програм сучасними психологічними технологіями, узагальнення і відпрацювання способів використання психологічних технік із метою полегшення їх засвоєння студентами.

Уважаємо, що процес фахової підготовки майбутнього психолога доцільно розкривати з урахуванням положень ціннісно-особистісного підходу. Такий підхід втілюється в освітньому процесі на засадах виокремлення аксіологічного поля в особистісному, професійному та соціальному просторах майбутнього фахівця. А психотехнології в такому разі реалізуються на основі інтеграції аксіологічного та особистісно орієнтованого підходів.

Основою аксіологічного підходу $є$ положення про цінності як детермінантне ядро особистісного розвитку (3.С. Карпенко) ${ }^{11}$, визнання учасників освітнього процесу активними ціннісно-мотивованими суб'єктами (Г.К. Радчук) $)^{12}$, сутнісними смислами яких є система особистісних цінностей, їх інтелектуальний, творчий та деонтологічний потенціали (М.С. Яницький) ${ }^{13}$. 3 аксіогенетичних позицій процес професійного розвитку студента-психолога відбувається завдяки інтерналізації останнім загальнолюдських цінностей на основі синергетичної, інтерперсональної співпраці викладача і студента (Т.С. Яценко) $^{14}$.

Сутність особистісно орієнтованого підходу реалізується завдяки положенням про особистість як безумовну цінність, що потребує

11 Карпенко 3.С. Аксіологічна психологія особистості : монографія. ІваноФранківськ : Лілея НВ, 2009. 512 с.

12 Радчук Г.К. Структурні та динамічні характеристики ціннісних орієнтацій студентів. Наука і освіта: наук.-практ. журн. Південного наукового Центру АПН Украӥни, 2009. № 5. С. 135-140.

${ }^{13}$ Яницкий М.С., Серый А.В., Пелех Ю.В. Ценностно-смысловая парадигма как основа постнеклассической педагогической психологии. Философия образования. 2013. № 1 (46). С. 175-186.

14 Яценко, Т. С. Внутрішня динаміка психіки та іï врахування в глибинній корекції. Науковий часопис Наџіонального педагогічного університету імені М. П. Драгоманова. Серія 12 : Психологічні науки : зб. наук. праџь. Київ, 2012. Вип. 37 (61). С. 6-10. 
шанобливого ставлення, визнання іï гідності, особистісних чеснот та індивідуальних властивостей. Кожна особистість спроможна бути відповідальною за себе і власне життя, оскільки постійно перебуває в цілеспрямованому «русі вперед i вгору» до обраної мети. Як «повноцінно функціональна» особистість вона має право обирати цінності й цілі та самостійно ухвалювати важливі рішення $(\text { К. Роджерс })^{15}$. Їй притаманна певна суб'єктність як авторство самореалізації і самоздійснення в процесі життєтворчості (B.О. Татенко $)^{16}$. Для саморозвитку, самовдосконалення та життєствердження особистості важливим $є$ позитивне ціннісне ставлення до неї з боку оточення (І.Д. Бех ${ }^{17}$, В.В. Рибалка ${ }^{18}$ )

Сутність иіннісно-особистісного підходу полягає в тому, що особистість та їі життя є безумовними і беззаперечними цінностями. Саме цінності структурують зміст ii аксіологічної самосвідомості, окреслюючи ключові аспекти іiі життєтворчості, та є особистісно значущими смислами. Для кожної особистості притаманна певна ієрархізована структура цінностей, яка істинна для неї й лише їй під силу їх гармонізація й синхронізація із загальнолюдськими цінностями. Така ієрархія є впорядкованим стрижнем, навколо якого вибудовується система ставлень, переконань, життєвих виборів та взаємодій. Соціально-психологічний простір особистості визначається іiі ціннісним ставленням до оточення, а осмислення власної системи цінностей сприяє формуванню ціннісного та відповідального ставлення до інших. Будь-які дії i вчинки людини, керовані іiі ціннісною свідомістю, будуть зорієнтовані на гармонізацію внутрішнього світу і взаємин 3 оточенням, оскільки прийняття й визнання іншого можливе лише в разі прийняття й визнання власної особистості, що забезпечує аксіологічну й гуманістичну спрямованість розвитку особистості та суспільства в цілому.

У контексті психологічних технологій фахової підготовки ціннісноособистісний підхід визначає зорієнтованість майбутнього психолога на власну аксіологічну систему координат i ціннісно-смислові перспективи професійного й соціального зростання. Водночас особистісна аксіосфера майбутнього фахівця не є сталою. Для кожного життєвого періоду, зокрема для етапу його професійної підготовки, притаманні певні домінантні цінності, завдяки яким він реалізує свій

${ }^{15}$ Роджерс К. Консультирования и психотерапия: новейшие подходы в области практической работы. Москва : Психотерапия, 2006. 512 с.

16 Татенко В.О. Про теоретико-методологічні засади психологічного дослідження суспільних явищ. Наукові студї із соціальної та політичної психології : зб. статей, 2000. Вип. 2 (5). С. 19-26.

${ }^{17}$ Бех І.Д. Особистісно орієнтований підхід: науково-практичні засади. Київ : Либідь, 2003. 344 с.

${ }_{18}$ Рибалка В.В. Аксіологічні основи психологічної культури особистості. Київ: АПН України, Ін-т пед. освіти і освіти дорослих; Ін-т обдарованої дитини; АПН і МОН України, Укр. наук.-метод. центр практ. психології і соц. роботи, 2009. 326 с. 
потенціал. Такими на етапах фахового становлення є особистісні й професійні якості, які водночас $є$ особистісними й професійними цінностями, що виявляються в ставленні майбутнього фахівця до об'єктивної дійсності та спрямовують його вибір смисложиттєвих установок у процесі життєствердження. У виборі професійного шляху особистісні цінності відіграють одну 3 ключових ролей, оскільки визначають спрямованість особистісного, професійного та соціального зростання фахівця. Так, соціально задана аксіологічна основа професійної підготовки психолога може бути інтеріоризована в систему особистісних та професійних цінностей тільки за умови вияву до них ціннісного ставлення.

Зважаючи на це, психотехнології професійної підготовки майбутнього психолога мають бути спрямовані не лише на забезпечення його теоретичними знаннями, а й на розкриття ціннісного потенціалу в процесі емпіричного опанування фаху. Адже для кожного, на думку R. Stratford ${ }^{19}$, істинним і достовірним є лише його власний досвід, який має більший вплив на особистість, аніж інтелектуальна інформація. Покладаючись на наукову позицію І.Д. Беха ${ }^{20}$, психологічні технології професійної підготовки мають сприяти формуванню чогось подібного до психологічного новоутворення, що відображало б безпосередню цінність для особистості узагальненої змістової сфери іiї фаховості. Через призму такого психологічного новоутворення майбутній психолог буде здатним усвідомити власний ціннісний образ професійного «Я» та ствердитись як професіонал. Сформовані на етапі професійної підготовки професійні цінності спонукатимуть особистість до пізнання себе в новому професійному «Я-образі» на основі ціннісного ставлення до себе як майбутнього фахівця.

Провідним положенням ціннісно-особистісного підходу в процесі реалізації психологічних технологій $\epsilon$ те, що для майбутнього психолога особистість іншого має стати центральним суб'єктом його професійної діяльності. Ціннісне ставлення майбутнього фахівця до особистості іншого пов'язане 3 переживанням безумовної цінності останнього, в якого завжди приховані внутрішні ресурси особистісного і професійного зростання, які не є відомими і йому самому. Зважаючи на це, необхідно актуалізувати психологічну підтримку й допомогу іншому для самостійного знаходження векторів особистісної змінюваності, самовдосконалення та самоздійснення. До того ж це визначає статус психолога як фахівця допоміжної професії, що реалізується через його ціннісне ставлення до іншого не лише в межах своїх професійних компетентностей, але й у межах побудови власних особистісних та соціальних взаємодій.

19 Stratford R. A competency approach to educational psychology practice: the implications for quality. Educational and child psychology. 2005. No 24. P. 5-11.

${ }^{20}$ Бех І.Д. Особистісно орієнтований підхід: науково-практичні засади. Київ : Либідь, 2003. 344 с. 
Ціннісно-особистісний підхід реалізується на основі таких принщипів, як об'єктивація особистісних цінностей; синергійність та співвідносність особистісних, професійних і соціальних цінностей; трансформація особистісних якостей у професійні цінності; проектування професійного «Я-образу».

Реалізація змісту вихідного положення об'єктиваиії особистісних цінностей майбутнього психолога полягає в тому, що в умовах освітньо-професійної активності для набуття фахового досвіду майбутні психологи засвоюють нові психологічні дисципліни і в процесі їх рефлексії виокремлюють такі особистісні утворення, які ідентифікуються 3 власними особистісними якостями. За умови ототожнення i прийняття виокремлених особистісних утворень майбутній фахівець прагне до повторної об'єктивації їх в особистісному просторі за рахунок переживання досвіду вирішення практичних ситуацій. Це об'єктивує означені особистісні якості, фіксуючи їх на свідомому рівні та транслюючи до надситуативного в ціннісну самосвідомість.

Згідно з принципом співвідносності та синергійності особистісних, професійних та соиіальних иінностей, укажемо на те, що майбутній психолог спочатку співвідносить особистісні цінності 3 цінностями обраного професійного шляху, усвідомлює та узгоджує нормативні професійні та соціальні цінності з особистісними, виробляючи нові ціннісні орієнтації. Останні в результаті набуття особистісної значущості перетворюються в цінності. Особистісні, професійні та соціальні цінності як структурні складники ціннісної самосвідомості співіснують у ній на умовах узгодженого й синергійного взаємозв'язку. Крім того, вибір майбутнім фахівцем соціальних цінностей зумовлюється його орієнтаціями на осмислення себе як фахової особистості, що синергізує розвиток у нього особистісних і професійних цінностей.

Принции трансформації особистісних якостей у професійні цінності дозволяє майбутньому психологові на підставі усвідомлення значущості особистісних якостей досягти такого рівня трансляції в структуру ціннісної самосвідомості, що визначає їх осмислення, прийняття та визнання як особистісних цінностей. Завдяки набуттю практичного досвіду в ціннісній самосвідомості актуалізуються процеси фільтрування, перехрещення, долучення, «виважування», що й визначає специфіку трансформації професійних ціннісних орієнтацій у професійні якості. У результаті постійного неодноразового їх практичного використання відбувається осмислення їх особистісної значущості в професії й подальша консолідація в структурі ціннісної самосвідомості як професійних цінностей.

Принци проектування професійного "Я-образу» визначає особливості побудови узагальненого образу майбутнього фахівця. Теоретико-емпіричний досвід сприяє закономірній змінюваності 
в структурі професійної та ціннісної свідомості майбутнього фахівця образу професійної діяльності. Для іiі відтворення і впровадження важливо символізувати у свідомості категорію образу. Для професійної діяльності майбутнього психолога така категорія пов'язана 3 проектуванням професійного «Я-образу». Спроектований професійний «Я-образ» майбутнього психолога дає можливість узагальнити професійні цінності таким чином, що вони конкретизують для нього специфіку спеціальності.

\section{2. Етапи аксіопсихології та специфіка їх реалізації в процесі професійної підготовки майбутнього психолога}

Процес реалізації аксіологічних психотехнологій у процесі фахової підготовки майбутнього психолога пов'язаний із врахуванням специфіки розвитку компонентів його ціннісної самосвідомості. Виокремлюють п'ять етапів вищезазначеного процесу, на яких відбувається структурування якісних особистісних утворень у межах певних аксіосфер (особистісної, професійної, соціальної) майбутнього психолога. Управління розвитком цих утворень здійснюється в контексті п’яти (відповідно до етапів) психотехнологій, алгоритм кожної з яких включає актуалізацію розуміння, пізнання та diєвість майбутнього психолога стосовно якостей та цінностей у аксіосферах ціннісної самосвідомості.

На нашу думку, спочатку алгоритм психотехнології професійної підготовки майбутнього психолога пов'язаний із підвищенням ефективності становлення певних особистісних утворень, що структуруються в особистісній аксіосфері. Алгоритм наступної психотехнології пов'язаний 3 ефективністю розвитку професійних ціннісних орієнтацій, які (ускладнюючись та інтегруючись) трансформуються в професійні цінності й функціонують у професійній аксіосфері майбутнього фахівця. Зрештою, ціннісне ставлення до іншого (як провідна детермінанта майбутньої професійної діяльності психолога) викристалізовує в структурі ціннісної самосвідомості соціальні орієнтири, які (ускладнюючись) перетворюються в соціальні цінності його соціальної аксіосфери. Слід підкреслити, що зазначені аксіосфери мають прямий і зворотний зв'язок, при цьому кожна з них, посилюючи свій внутрішній потенціал, розповсюджується на вищі етапи становлення ціннісної самосвідомості. Водночас аксіосфери, які нові (професійна та соціальна) для майбутнього фахівця, залучаються до взаємозв'язку з попередньою (особистісною) і транслюються в такій синергії до інтегративного зв'язку, визначаючи передбачувану продуктивність результату. Це приводить до більш глобалізованого й інтегрованого якісного утворення - інтеграла професійної цінності, який і буде визначати стійку переконаність майбутнього психолога щодо особистісного вибору професії. 
На першому етапі фахової підготовки реалізується психотехнологія "Осмислення особистісних цінностей майбутнім психологом", у результаті чого підвищуються показники емоційноціннісного, когнітивного та мотиваційно-поведінкового рівнів ціннісної самосвідомості. На тлі цього актуалізується ціннісне самоставлення, що дає можливість майбутньому психологові синергезувати процес власного розуміння особистісних якостей. Більш широке включення майбутнього фахівця в освітньо-професійну діяльність закладів вищої освіти визначає процес подальшого пізнання цих якостей на підставі виявлення та прийняття як позитивних, так і негативних модальностей у його «Я-образі». Актуалізація ціннісно-смислової рефлексії сприяє самоприйняттю цих особистісних якостей майбутнім психологом, котрі структурують його особистісний простір. Активізація дієвості щодо прийнятого спектра особистісних орієнтацій та якостей сприяє їх самовизнанню й диференціації того, що відповідає чи не відповідає критеріям ідеального «Я-образу». У результаті осмислення майбутнім психологом ціннісності окремих особистісних якостей, вони утверджуються в новій формі в епіцентрі реального «Я-образу». Співвідносячи їх із модальностями ідеального «Я-образу», майбутній фахівець утверджує їх ціннісність, трансформуючи таким чином у поле особистісної аксіосфери як власні особистісні цінності.

На другому етапі фахової підготовки реалізується технологія «Осмислення професійних цінностей та здійснення особистісного вибору спеціалізації майбутнім психологом». У ході освітньопрофесійної діяльності майбутнього фахівця в закладі вищої освіти відбувається процес розуміння значущих професійних орієнтацій, які відіграють провідну/суттєву роль у побудові майбутнього професійного шляху. Розширення й ускладнення когнітивної інформації дають можливість майбутньому фахівцеві виокремити й вийти на рівень ціннісного пізнання низки професійних якостей. Водночас розвиток дієвості на засадах навчально-практичної діяльності дає можливість майбутньому психологові виокремити ціннісність професійних якостей і перенести їх в епіцентр реального професійного «Я-образу».

На третьому етапі фахової підготовки реалізується технологія "Осмислення соціальних цінностей майбутнім психологом». У результаті актуалізації в ціннісній самосвідомості майбутнього фахівця особистісних та професійних цінностей, виникає тенденція до розуміння ним соціальних орієнтирів як таких, що детермінують психологічну підтримку чи допомогу іншому. Соціальна орієнтація на психологічну допомогу іншому визначає ускладнення розвитку емоційно-ціннісного, когнітивного та мотиваційно-поведінкового рівнів ціннісної самосвідомості майбутнього психолога. Оптимізований процес освітньо-професійної діяльності в закладах вищої освіти визначає розвиток ціннісного пізнання іншого. У полі соціальної аксіосфери в результаті самоприйняття ті соціальні орієнтири, які 
усвідомлюються майбутнім психологом як суттєві соціальні якості для майбутньої професійної діяльності, імплементуються в епіцентр ідеального професійного «Я-образу». Водночас посилюється цілеспрямована мотивація майбутнього фахівця на активізацію дієвості стосовно іншого, що забезпечує можливість самовизнання та трансформації соціальних якостей у реальний професійний «Я-образ» та їх консолідацію в соціальній аксіосфері як соціальних цінностей.

На четвертому етапі фахової підготовки реалізується технологія "Розвитку аксіоідентичності майбутнього психолога", в межах якого посилюється зв'язок та синергія особистісних, професійних та соціальних цінностей усіх аксіосфер майбутнього психолога. Це призводить до конструювання складного особистісного утворення складника інтеграла професійної цінності - аксіоідентичності. У процесі навчання посилюється професійна поінформованість майбутнього фахівця, актуалізуючи алгоритми розуміння та пізнання і якісно збагачуючи емоційно-ціннісний, когнітивний та мотиваційноповедінковий рівні його ціннісної самосвідомості. Таке ускладнення змісту аксіосвідомості інтенсифікує входження та ототожнення особистісних, професійних i соціальних цінностей із реальним професійним «Я-образом». Окреслені ідентифікаційні процеси дають можливість майбутньому психологові утвердити в епіцентрі реального професійного «Я-образу» індивідуальне особистісно-смислове утворення - особистісну ідентичність «Я-психолог». Загалом, під час фахової підготовки відбувається активізація дієвості в межах спеціальності та освітньої програми, що визначає посилення тенденцій до виокремлення суб’єктів співпраці в подальшій професійній діяльності.

На n'ятому еmani фахової підготовки втілюється технологія "Самореалізації домінантних цінностей інтеграла професійної цінності майбутнього психолога». Завдяки цьому в майбутнього психолога активізується спрямованість на теоретико-прикладний досвід, що надає можливість фахівцеві підсвідомо виконувати алгоритми розуміння, пізнання та дієвості, які посилюють його ціннісне самовизнання особистісної цінності «Я-психолог», утверджуючи останню в особистісній аксіосфері як аутоціннісність. I зрештою, саморегуляція соціальних цінностей підводить до самовизнання й утвердження в зазначеному «Я-образі» соціальної цінності «Я-Інший», Інший-Я» на рівні соціальної аксіосфери як афіляціннісності. Взаємозв'язок та синергійність окреслених особистісних утворень, які відображають для майбутнього психолога цінність власної особистості в професії, цінність останньої та результатів професійної діяльності стосовно іншого, знаменують появу стійкого особистісного утворення - інтеграла професійної цінності.

У процесі реалізації психологічних технологій ключовим механізмом є иіннісно-особистісна рефлексія, за допомогою якої майбутній психолог вдається до переосмислення і визначення для себе 
значущості й самовартісності того, що набуто в процесі життєтворчості, та того, що в перспективі має визначати успішність його особистісного, професійного і соціального самовдосконалення. Механізм ціннісно-особистісної рефлексії визначає динаміку трансляції від особистісних якостей до особистісних цінностей. Відповідно до засобів i технік, які реалізуються під час упровадження психотехнологій, об'єктами особистісної рефлексії є ціннісні орієнтації та особистісні, професійні й соціальні цінності майбутнього фахівця. Використані під час реалізації психотехнологій алгоритми сприяють внутрішнім перетворенням ціннісної самосвідомості на засадах механізму ціннісно-особистісної рефлексії таким чином, що ціннісні орієнтації трансформуються в особистісні, професійні чи соціальні якості i, відповідно, в особистісні, професійні чи соціальні цінності. Однорівнево актуалізується механізм ціннісно-професійної рефлексії ma інтеріоризаціï, який дозволяє виокремити професійні орієнтири, транслювати їх до професійних якостей i надалі до професійних цінностей. До них долучається механізм иіннісно-соиіальної рефлексії ma інтеріоризації, який виокремлює соціальні орієнтири, транслює їх до соціальних якостей i, відповідно, до соціальних цінностей у системі «Я-Інший». Пізніше активується механізм ціннісної ідентифікації, що дозволяє майбутньому фахівцеві визначити себе як психолога, переконатись у відповідності власних компетенцій певній освітній програмі. Насамкінець механізм циннісної саморегуляції дає можливість майбутньому фахівцеві чітко усвідомити й осмислити для самого себе спеціальність психолога як аутоціннісність, визнати для себе певну спеціалізацію як профціннісність.

Поетапність становлення ціннісної самосвідомості майбутнього психолога є стратегічно визначальною в технологіях його професійної підготовки, оскільки дозволяє врахувати гетерохронність розвитку складників та встановити взаємозв'язок між особистісною, професійною та соціальною аксіосферами. У процесі синергійності цінностей цих аксіосфер структуруються складніші особистісні утворення - домінантні цінності, що на метарівні для майбутнього фахівця персоналізують аксіологічну сутність самосвідомості, яка й кристалізує його ціннісне ставлення до себе, професії та іншого. Утвердження домінантних цінностей свідчить про те, що майбутній психолог від вирішення часткових особистісних, професійних та соціальних проблем піднімається на більш глобальний рівень усвідомлення власної цінності в професії й суспільстві. Домінантними цінностями майбутнього психолога $є$ такі: «Я-психолог» (особистісна аксіосфера), відповідно до спеціалізації «Я-тренер», «Я-консультант», «Я-соціальний психолог» тощо (професійна аксіосфера) та «Я-Інший, Інший-Я» (соціальна аксіосфера). Сукупність зазначених домінант створює інтеграл професійної цінності майбутнього психолога як динамічного й поліфункціонального психологічного утворення, що 
слугує стрижневим орієнтиром процесу його самоствердження й життєтворення.

Таким чином, логіка функціонування моделі психологічних технологій підготовки майбутнього психолога (див. рис. 1) відповідає вищеоокресленим положенням обраного підходу. Її змістове навантаження віддзеркалює горизонтальну й вертикальну площини розвитку інтеграла професійної цінності майбутнього фахівця. У горизонтальній площині поетапно реалізуються взаємопов'язані психотехнології становлення складників інтеграла та його компонентів, спрямованих на розвиток розуміння, пізнання та дієвості особистості й актуалізацію модусів самоставлення, самоприйняття та самовизнання в межах певної аксіосфери майбутнього психолога. По вертикалі опосередковано здійснюються процеси розвитку й утвердження домінантних цінностей інтеграла професійної цінності майбутнього психолога. Розвиток його аутоціннісності (як усвідомлення власної значущості в професії) відбувається на основі ускладнення особистісних цінностей професійними та соціальними. Профціннісність пов'язана 3 усвідомленням майбутнім фахівцем власної значущості як консультанта, тренера соціального психолога, психолога-реабілітолога, політичного психолога тощо та відбувається в процесі синергії професійних і соціальних цінностей. Афіляціннісність майбутнього психолога $є$ результатом усвідомлення ним особистіснопрофесійної цінності та власної значущості для іншого як помічника (наставника, фасилітатора) в складних життєвих обставинах.

Метою технології першого етапу $\epsilon$ осмислення майбутнім психологом особистісних цінностей. Алгоритм технології побудований таким чином, щоб сприяти майбутньому фахівцеві в рефлексії особистісних якостей, переосмисленні позитивних і негативних сторін у пізнанні себе та дієвому утвердженні особистісної цінності. При цьому утвердження особистісних цінностей вирішується не лише технологією першого етапу. Їх кристалізація відбувається впродовж подальших років підготовки, створюючи основу для розвитку й інтеграції професійних та соціальних цінностей. 


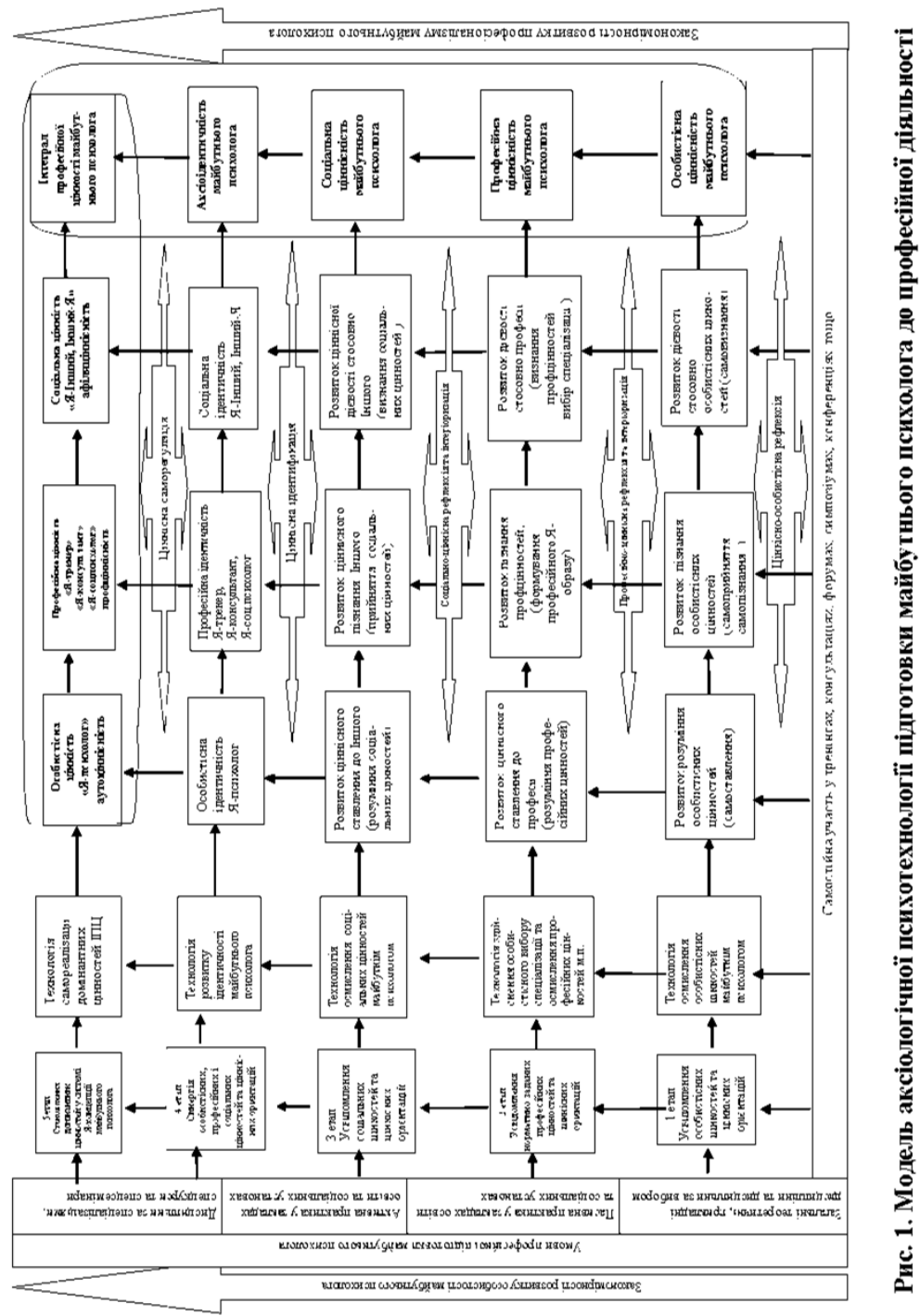


У процесі реалізації технології другого етапу відбувається осмислення професійних цінностей та здійснення особистісного вибору спеціалізації майбутнім психологом. Алгоритм технології дозволяє майбутньому фахівцеві відрефлексувати професійні орієнтири та якості, співвіднести наявні професійні здібності з вимогами спеціальності й програмними результатами освітньої програми та, інтеріоризуючи дефіцитарні професійні якості, вибудувати реальний професійний «Я-образ» й утвердити професійні якості - професійні цінності, які окреслюють ціннісно-смислову сутність як конкретної кваліфікації, так і спеціальності в цілому.

Алгоритм технології третього етапу орієнтований на осмислення соціальних цінностей майбутнім психологом. Рефлексія соціальних орієнтирів дозволяє майбутньому фахівцеві визначити значущість власної особистості щодо іншого, усвідомити конгруентні й інконгруентні аспекти щодо нього, інтеріоризувати недостатні й соціально бажані орієнтири, утверджуючи їх як соціальні цінності. Метою технології четвертого етапу $\epsilon$ розвиток аксіоідентичності майбутнього психолога. Алгоритм технології орієнтований на синтез особистісної, професійної та соціальної ідентичностей майбутнього фахівця. На основі ідентифікації в кожній аксіосфері виокремлюються певні цінності, з якими особистість ототожнює себе як психолога, як виконавця певних професійних ролей і функцій, зокрема консультанта, тренера, соціального психолога, психолога-реабілітолога тощо. Наявність таких ототожнень свідчить про взаємозв'язок, трансформацію й інтеграцію особистісних утворень майбутнього психолога, які консолідуються в його інтеграл професійної цінності.

Метою технології п'ятого етапу $є$ самореалізація домінантних цінностей як складників інтеграла професійної цінності майбутнього психолога. Алгоритми технології орієнтовані на самоактуалізацію, самоствердження та самореалізацію майбутнім психологом домінантних цінностей, сукупність яких структурує його інтеграл професійної цінності. Такими є «Я-психолог» (особистісна аксіосфера), «Я-консультант», «Я-тренер», «Я-соціальний психолог», «Я-психологреабілітолог» тощо (професійна аксіосфера), «Я-Інший, Інший-Я» (соціальна аксіосфера).

Оскільки концептуальна модель ціннісно-особистісної технології професійної підготовки майбутнього психолога реалізується під час освітньо-професійної діяльності студента в закладі вищої освіти, то однією з ії ознак має бути співробітництво й активна довірлива взаємодія професорсько-викладацького складу кафедр, груп забезпечення освітніх програм i студента-психолога, що стимулювало б формування внутрішніх i зовнішніх чинників професійного самовизначення майбутнього фахівця, зокрема професійної ідентичності, вмотивованості та гармонізації реального й ідеального професійного «Я-образу». 


\section{ВИСНОВКИ}

Отже, в сучасних умовах, коли відбувається реформування освітньої системи, майже одночасно збільшується потік економічних, політичних та загальнолюдських криз у результаті військових дій на Сході України, перебігу пандемії COVID-19, стрімкого зростання внутрішньої й зовнішньої мобільності громадян, тому важливо актуалізувати ціннісну сферу людини, особливо фахівців допоміжних професій. Аксіологічно орієнтовані технології підготовки майбутнього психолога варто розглядати як цілісне функціонування аксіопсихологічної системи, в якій всі складники взаємопов'язані й синергізовані, а успішність упровадження й проходження одних етапів забезпечує ефективність реалізації наступних. Водночас психотехнології не лише спрямовані на підготовку кваліфікованих майбутніх психологів і розвиток їх інтеграла професійної цінності, а й закладають витоки їх аксіологічного світогляду та життєствердження.

Інтеграл професійної цінності майбутнього психолога варто розглядати як особистісне інтегративне утворення, успішність формування якого гарантує повноцінне залучення психологапочатківця до професійної діяльності 3 розумінням усіх іiі ризиків і переваг. Наявність внутрішнього особистісно-професійного стрижня, яким $\epsilon$ інтеграл професійної цінності, слугує певним ресурсним базисом для роботи з кліснтами, захищає від швидкого емоційного вигорання на початкових етапах занурення в життєві проблеми тих, хто потребує психологічної підтримки. Водночас інтеграл $є$ стимулом до самореалізації й професійного зростання майбутнього психолога.

Презентований варіант аксіологічної психотехнології професійної підготовки майбутніх психологів $\epsilon$ результатом тривалого теоретикоемпіричного вивчення, апробації й практичного втілення в процес функціонування факультету психології Національного педагогічного університету імені М.П. Драгоманова. Утім у світлі переходу освітнього процесу закладів вищої освіти і професійної діяльності психолога в онлайн-формат виникає необхідність розгортання деяких етапів технології з урахуванням аспектів цифровізації, адаптивності, масштабності i, що важливо, збереження необхідного результату в процесі гнучкого реагування на бурхливі інноваційні зміни. У цьому й полягатимуть перспективи нашого подальшого дослідження в межах ціннісно-особистісної парадигми проблеми формування інтеграла професійної цінності майбутнього психолога.

\section{АНОТАЦІЯ}

У час глобальних потрясінь та ціннісно-смислової переоцінки соціально-політичних процесів розвитку суспільства, масштабної цифровізації та диджиталізації міжособистісної взаємодії людини фахова діяльність психолога набуває нових аспектів значущості. Саме 
психологові в кризово-біфуркаційні моменти життя особистості необхідно віднайти для неї ті смисли, які стануть основою подальшого життєтворення. Але для цього психолог сам має володіти таким аксіологічним осердям, розвиток якого і передбачає запропонована аксіологічна психотехнологія його професійної підготовки в закладах вищої освіти.

У статті презентовано результати теоретико-емпіричного вивчення проблеми та впровадження аксіологічної психотехнології професійної підготовки майбутніх психологів у закладах вищої освіти. Розкрито сутнісний зміст ціннісно-особистісної психологічної технології фахового зростання особистості майбутнього психолога. В основу окресленої технології покладено особистісні, професійні та соціальні цінності особистості, які репрезентують ії особистісну, професійну та соціальну аксіосфери. Алгоритм технології побудований таким чином, щоб сприяти майбутньому фахівцеві в рефлексії особистісних якостей, переосмисленні позитивних і негативних сторін у пізнанні себе та дієвому утвердженні особистісної цінності. Описано п’ять етапів реалізації психотехнології. Визначено й обгрунтовано ключові механізми (ціннісно-особистісну рефлексію, інтеріоризацію, ціннісну ідентифікацію, ціннісну саморегуляцію) та алгоритми (розуміння, пізнання, дієвість) актуалізації якостей майбутнього психолога стосовно аксіосфер ціннісної самосвідомості. Запропоновано одним із критеріїв визначення міри готовності фахівця до самостійної практичної психологічної діяльності розглядати рівень сформованості в нього інтеграла професійної цінності, який $є$ ціннісно-смисловим стрижнем його аксіологічного світогляду і внутрішнім опертям фахової конкурентоспроможності й життєствердження загалом.

\section{ЛIТЕРАТУРА}

1. Асмолов А.Г. Психология личности: культурно-историческое понимание развития человека. Москва : Смысл: «Академия». 2007. $528 \mathrm{c}$.

2. Бех І.Д. Особистісно орієнтований підхід: науково-практичні засади. К.: Либідь. 2003. 344 с.

3. Булах I., Волошина В., Лохвицька Л. Сучасні освітні психотехнології професійної підготовки майбутніх психологів. 2019. URL: http://ekmair.ukma.edu.ua/handle/123456789/17080 https://doi.org/10.18523/2617-2348.2019.2.20-29

4. Василюк Ф.Е. От психологической практики к психотехнической теории. Психологическое консультирование и психотерапия: хрестоматия / под ред. А.Б. Фенько, Н.С. Игнатьевой, М.Ю. Локтаева. Москва, 1999. Т. 1.288 с.

5. Васьківська С.В. Основи психологічного консультування. Київ : Четверта хвиля. 2004. 256 с. 
6. Волошина В.В. Психологічні технології підготовки майбутнього психолога. Вінниця: ТОВ «Нілан-ЛТД». 2015. 391 с.

7. Выготский Л.С. Проблемы развития психики: т. 3. Собрание сочинений: в 6-ти т. / под ред. А.М. Матюшкина. Москва : Педагогика. $1983.368 \mathrm{c}$.

8. Казанцева Т.А. Особенности личностного развития и профессионального становления студентов-психологов : дисс. ... канд. психол. наук : 19.00.11. Москва, 2000. 248 с.

9. Карпенко 3.С. Аксіологічна психологія особистості : монографія. Івано-Франківськ : Лілея НВ. 2009. 512 с.

10. Книш А. Є. Структура особистісної готовності до професійної діяльності майбутніх психологів-тренерів. Теорія і практика управління соціальними системами. 2014. № 1. С. 84-91.

11. Лежнина Л.В. Комплексная технология разбора кейсов в подготовке психологов образования. Психология образования: современное состояние и перспективы: материалы II Всеросс. науч.практ. конф. / под общ. ред. Е.Ю. Пряжниковой. Славянск-на-Кубани: Издательский центр СГПИ. 2008. С. 303-306.

12. Помиткін Е.О. Актуальні питання духовно орієнтованої підготовки та діяльності практичного психолога. Актуальные проблемы профессиональной подготовки практических психологов. Сб. науч. трудов. Приложение № 10 (15) к научному журналу «Персонал». № 5 (59). 2000. С. 37-39.

13. Радчук Г.К. Структурні та динамічні характеристики ціннісних орієнтацій студентів. Наука і освіта: наук.-практ. журн. Південного наукового Центру АПН Украӥни. 2009. № 5. С. 135-140.

14. Рибалка В.В. Аксіологічні основи психологічної культури особистості. Київ : АПН України, Ін-т пед. освіти і освіти дорослих; АПН і МОН України, Укр. наук.-метод. центр практ. психології і соц. роботи. 2009. $326 \mathrm{c.}$

15. Роджерс К. Консультирования и психотерапия: новейшие подходы в области практической работы. Москва : Психотерапия. 2006. 512 c.

16. Ситников А.П. Современные прикладные психотехнологии: процесс и язык коммуникации. Москва : РАУ. 1992. 276 с.

17. Татенко В.О. Про теоретико-методологічні засади психологічного дослідження суспільних явищ. Наукові студіi iз соиіальної та політичної психологї : зб. статей. 2000. Вип. 2 (5). C. $19-26$.

18. Титаренко Т.М. Життєві домагання і професійне становлення особистості практичного психолога. Практична психологія та сочіальна робота. № 4. 2003. С. 15-18.

19. Шнейдер Л.Б. Профессиональная идентичность : монография. Москва : МОСУ. 2001. 272 с. 
20. Яницкий М.С., Серый А.В., Пелех Ю.В. Ценностно-смысловая парадигма как основа постнеклассической педагогической психологии. Философия образования. 2013. № 1 (46). С. 175-186.

21. Яценко Т.С. Внутрішня динаміка психіки та ii врахування в глибинній корекції. Науковий часопис Національного педагогічного університету імені М.П. Драгоманова. Серія 12 : Психологічні науки : зб. наук. праць. Київ. 2012. Вип. 37 (61). С. 6-10.

22. Hatcher R.L. Initial training in professional psychology: the practicum competencies outline. Training and education in professional psychology. 2007. Vol. 1, No 1. P. 49-63.

23. Stratford R. A competency approach to educational psychology practice: the implications for quality. Educational and child psychology. 2005. No 24. P. 5-11.

24. Chidley S., Stringer P. Addressing barriers to implementation: an Implementation Framework to help educational psychologists plan work with schools. Educational Psychology in Practice. 2020. C. 1-11. doi:10.1080/02667363.2020.1838448

25. Wagstaff C. R. D., Quartiroli A. Psychology and psychologists in search of an identity: what and who are we, and why does it matter? Journal of Sport Psychology in Action. 2020. C. 1-12. doi: $10.1080 / 21520704.2020 .1833124$

26. Wimmer-Puchinger B., Wolf H., Klimesch A. On the Situation of Professional Psychology in the Austria Health Care System. PSYCHOLOGISCHE RUNDSCHAU. 2020. T. 71. №. 4. C. 372-383. doi: 10.1026/0033-3042/a000508

\section{Information about the authors:} Bulakh I. S.,

Dr. in Psychology, Professor, Professor at the Department of Theoretical and Advisory Psychology of the Faculty of Psychology National Pedagogical Dragomanov University 9, Pyrohova str., Kyiv, 02000, Ukraine

Voloshyna V. V.,

Dr. in Psychology, Associate Professor, Professor at the Department of Theoretical and Advisory Psychology of the Faculty of Psychology National Pedagogical Dragomanov University 9, Pyrohova str., Kyiv, 02000, Ukraine 